\title{
PENTINGNYA PELATIHAN DAN PENGEMBANGAN SUMBER DAYA MANUSIA TERHADAP PENINGKATAN KINERJA KARYAWAN PADA KFC JEMBER
}

\section{THE IMPORTANCE OF TRAINING AND DEVELOPMENT OF HUMAN RESOURCES TO IMPROVING EMPLOYEE PERFORMANCE IN KFC JEMBER}

\author{
Luckman Ashary,S.E.,.M.M
}

Email : luckman.ashary@yahoo.com

Prodi Manajemen, Fakultas Ekonomi, Universitas Abdurachman Saleh Situbondo

\begin{abstract}
ABSTRAK
Tujuan penelitian ini adalah untuk mengetahui peran dan evaluasi manajer SDM KFC Jember dalam meningkatkan kinerja karyawan serta mengetahui metode pelatihan dan pengembangan yang diterapkan bagi karyawan KFC Jember kendala- yang dihadapi Manajer KFC Jember dalam melakukan peningkatan kinerja karyawan. Jenis penelitian ini menggunakan pendekatan studi kasus dengan metode deskriptif kualitatif. Lokasi Penelitian dilakukan pada karyawan KFC Jember yang beralamat di Jalan Gajah Mada No.74, Jember Kidul, Kaliwates, Kabupaten Jember, Jawa Timur. Theoretical sampling yang digunakan pada penelitian ini adalah purposive sampling. Hasil penelitian menyebutkan metode pelatihan calon karyawan yang digunakan KFC Jember adalah Lecture dan on the job training. Metode pengembangan karyawan yang digunakan KFC Jember adalah job rotasi lalu dengan memakai kembali metode pelatihan (on the job training) dan understudy. Pelatihan calon karyawan dan pengembangan karyawan yang dilakukan telah sesuai dengan prosedur yang telah ditetapkan oleh perusahaan.

Kata Kunci : Pelatihan; Pengembangan Karyawan; Kinerja Karyawan
\end{abstract}

\section{ABSTRACT}

The purpose of this study was to determine the role and evaluation of KFC Jember HR managers in improving employee performance and knowing the training and development methods applied to KFC Jember employees constraints faced by KFC Manager Jember in improving employee performance. This type of research uses a case study approach with qualitative descriptive methods. Location The study was conducted on KFC Jember employees whose address is at Gajah Mada Street No.74, Jember Kidul, Kaliwates, Jember Regency, East Java. Theoretical sampling used in this study was purposive sampling. The results of the study mentioned the prospective employee training methods used by KFC Jember were Lecture and on the job training. The employee development method used by $K F C$ Jember is a job rotation and then uses the on the job training method and understudy. Prospective employee training and employee development carried out in accordance with procedures established by the company.

Keywords: Training; Employee Development; Employee performance 


\section{PENDAHULUAN}

Sumber daya manusia merupakan unsur yang penting dalam kegiatan operasional perusahaan. Seperti apapun hebatnya sistem kualitas manajemen, secara mutlak mereka semuanya bergantung pada kegiatan manusia dalam usahanya untuk berhasil. Sumber daya manusia merupakan penentu akhir (final determinants) dari keefektifan sistem manajemen kualitas dalam praktek. Supaya potensi sumber daya manusia ini dapat digunakan secara maksimal memerlukan suatu pengelolaan yang baik, meliputi kebijakan-kebijakan manajemen, prosedur maupun sistem yang diterapkan. Dalam suatu perusahaan, pengelolaan ini diserahkan kepada divisi sumber daya manusia/departemen personalia yang bertanggung jawab untuk mendapatkan, memberdayakan dan memelihara sumber daya manusia. Semakin pentingnya peran manajemen sumber daya manusia di dalam organisasi telah mendorong munculnya upaya evaluasi terhadap pelaksanaan divisi tersebut. Tidak dapat dipungkiri bahwa divisi sumber daya manusia dapat melakukan penyimpangan dan kesalahan dalam pelaksanaan aktivitasnya, ataupun ketidaksesuaian dalam perumusan kebijakan, yang disebabkan adanya perubahan - perubahan lingkungan persaingan.

Karyawan baru sering merasa tidak pasti perihal peran dan tanggung jawab mereka dalam perusahaan sehingga dapat diasumsikan bahwa pelatihan dan pengembangan sangatlah penting bagi karyawan dalam meningkatkan kompetensi diri mereka terhadap pengusaan pekerjaan ataupun tanggung jawab yang akan dilakukannya. Dalam dunia kerja, pelatihan dan pengembangan sering dilakukan sebagai upaya meningkatkan kinerja para karyawan yang dianggap belum mampu untuk mengemban pekerjaannya karena faktor tingkat pendidikan. Secara deskripsi tertentu potensi para pekerja mungkin sudah memenuhi syarat administrasi pada pekerjaanya, tapi secara aktual para pekerja harus mengikuti atau mengimbangi perkembangan perusahaan sesuai dengan tugasnya.

Hal ini yang mendorong perusahaan untuk memfasilitasi pelatihan dan pengembangan karir para tenaga kerja guna mendapatkan hasil kinerja yang baik, efektif dan efisien. Perusahaan yang efisien dan efektif dalam Kinerja Keuangan 
dan Kinerja Manusia tentu akan dengan lebih cermat dalam menghadapi Persaingan Bisnis Global. Baik efektivitas maupun efisiensi mengharuskan perusahaan maupun pribadi untuk terus menetapkan target, menganalisa kerja dengan seksama, mengatur prioritas, dan senantiasa berfokus pada tugas. Perusahaan yang gagal meraih target yang telah ditetapkan tidak bisa disebut sebagai sebuah perusahaan yang efisien maupun efektif. Pencapaian target di sini bisa dinyatakan sebagai sebuah indeks obyektif dari peningkatan efektivitas perusahaan.

Hal yang dilakukan oleh Kentucky Fried Chicken (KFC) Jember, yaitu melakukan pelatihan dan pengembangan karyawan di perusahaan mereka. Semua proses pelatihan dan pengembangan karyawan baik karyawan baru atau pemilihan bagian dilakukan di DTO (District Training Officer) yang berpusat di Plaza Surabaya selama 2 minggu, minggu pertama mengikuti teori didalam kelas, dan minggu kedua praktek langsung kelapangan. Untuk pengembangan karyawan di KFC Jember setiap beberapa bulan biasanya manajer memindahkan karyawan yang rajin dan berpotensi kedivisi lain, untuk mempelajari hal-hal yang baru.

KFC Jember telah memiliki fungsi manajemen SDM (Sumber Daya Manusia) yang dibawahi oleh manajer HRD (Human Resources Development). Didalam industri ini, KFC Jember tidak hanya menjual produk makanan dan minuman saja, tetapi juga service / pelayanan yang dapat memuaskan konsumen. Dalam mendapatkan service yang berkualitas dibutuhkan SDM yang berkualitas pula. Diperlukan evaluasi dalam proses pelatihan dan pengembangan bagi SDMnya yang sifatnya berkelanjutan sehingga kualitas layanan yang diberikan karyawan dapat dimaksimalkan dan konsumen juga merasa puas atas pelayanan yang telah diberikan dan memberikan pengakuannya.

Pada penelitian ini, peneliti lebih memfokuskan langsung pada proses pelatihan dan pengembangan SDM yang ada di KFC Jember. Dalam pertumbuhan dan pengembangan usaha, perusahaan perlu memperkaya SDM dalam segi kualitas dan kuantitas untuk mencapai visi dan misi perusahaan yang nantinya menjadi keunggulan kompetitif dan menunjang pengembangan usaha perusahaan. 


\section{Rumusan Masalah}

Berdasarkan latar belakang di atas, rumusan masalah dalam penelitian ini sebagai berikut :

1. Bagaimana peran manajer SDM KFC Jember dalam meningkatkan kinerja karyawan?

2. Bagaimana evaluasi yang dilakukan Manajer KFC Jember dalam meningkatkan kinerja karyawan?

3. Metode pelatihan dan pengembangan apakah yang tepat diterapkan bagi karyawan KFC Jember?

4. Kendala-kendala apa saja yang dihadapi Manajer KFC Jember dalam melakukan peningkatan kinerja karyawan?

\section{Tujuan Penelitian}

Adapun tujuan yang akan dicapai dalam penelitian ini adalah:

1. Untuk mengetahui sejauh mana peran manajer SDM KFC Jember dalam meningkatkan kinerja karyawan

2. Untuk mengetahui bagaimana evaluasi yang dilakukan Manajer KFC Jember dalam meningkatkan kinerja karyawan

3. Untuk mengetahui metode pelatihan dan pengembangan yang tepat diterapkan bagi karyawan KFC Jember

4. Untuk mengetahui Kendala-kendala apa saja yang dihadapi Manajer KFC Jember dalam melakukan peningkatan kinerja karyawan

\section{METODE PENELITIAN}

\section{Jenis Penelitian}

Jenis penelitian ini menggunakan pendekatan studi kasus dengan metode deskriptif kualitatif, yaitu penelitian yang bermaksud untuk memahami fenomena tentang apa yang dialami oleh subjek penelitian misalnya perilaku, persepsi, motivasi, tindakan, dan lain-lain; secara holistik, dan dengan cara deskripsi dalam bentuk kata - kata dan bahasa, pada suatu konteks khusus yang alamiah dan 
dengan memanfaatkan berbagai metode alamiah (Moleong, 2011:6). Penelitian ini juga bertujuan untuk mengurai sifat atau karakteristik dari suatu fenomena tertentu dan hanya mengumpulkan fakta, menguraikan secara menyeluruh dan teliti sesuai dengan persoalan yang akan dipecahkan (Umar, 2005:33-34). Penelitian Deskriptif berfokus pada penjelasan sistematis tentang fakta yang diperoleh saat penelitian dilakukan (Sanusi, 2011).

\section{Analisis Data}

Penelitian ini menggunakan teknis analisis data kualitatif. Menurut Moleong (2011:288-291) proses analisis data dimulai dengan : (1) Menelaah seluruh data dari berbagai sumber, pada tahap ini seluruh data yang diperoleh dari wawancara, pengamatan yang sudah dituliskan dalam catatan di lapangan, dan dokumen dokumen perusahaan atau data perusahaan, ditelaah keterkaitan satu sama lain. (2) Reduksi data adalah upaya mengidentifikasi bagian terkecil dalam data yang memiliki makna jika dikaitkan dengan fokus dan masalah penelitian. satu upaya untuk membuat abstraksi. Hal ini akan membentuk rangkuman inti dari setiap data sesuai dengan tujuan penelitian. Setelah dilakukan reduksi data - data tersebut disusun dalam satuan - satuan ( Unitizing ). (3) Kategorisasi, adalah upaya memilah setiap satuan data ke dalam bagian-bagian yang memiliki kesamaan. Hal ini dapat dilakukan dengan memberikan coding pada gejala - gejala / hasil - hasil dari seluruh proses penelitian. Kategori disusun atas dasar pemikiran, institusi, pendapat, atau kriteria tertentu. (4) Pemeriksaan keabsahan data. Untuk menetapkan keabsahan data diperlukan teknik pemeriksaan, teknik pemeriksaan pada penelitian ini menggunakan metode triangulasi data. Triangulasi adalah teknik keabsahan data yang memanfaatkan sesuatu yang lain di luar data itu untuk keperluan pengecekan / sebagai pembanding terhadap data itu. (5) Penafsiran data, untuk menjawab rumusan masalah dilakukan dengan deskripsi analitik, yaitu rancangan dikembangkan dari kategori - kategori yang ditemukan dan mencari hubungan yang disarankan atau yang muncul dari data. Dalam penelitian ini, penulis merasa cukup hanya menggunakan metode pengujian data dengan 
triangulasi sumber. Teknik triangulasi dengan sumber data dilakukan dengan (dalam Bungin, 2009:265) : (1) Membandingkan hasil wawancara dengan isi suatu dokumen yang berkaitan. (2) Membandingkan keadaan dan perspektif seseorang dengan berbagai pendapat dan pandangan orang. (3) Membandingkan data hasil pengamatan dengan hasil wawancara.

\section{Tahapan Analisis Data}

Analisis pada kajian ini dilakukan melalui analisis data primer dari hasil survei kepada Manajer KFC Jember berserta Supervisor dan karyawan. Kajian ini dilakukan dalam beberapa tahapan analisis sebagai berikut:

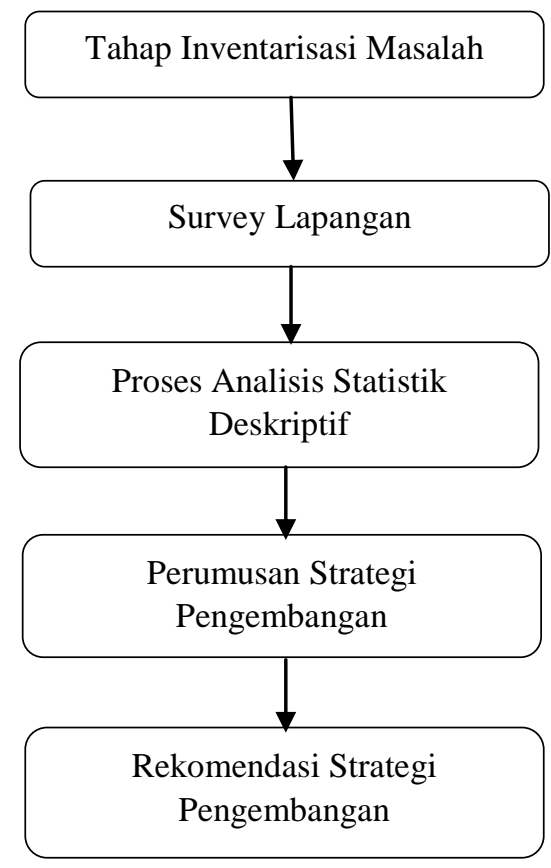

Gambar 1. Tahapan Analisis Data

\section{Penentuan Lokasi Dan Waktu Penelitian}

Lokasi Penelitian dilakukan pada karyawan KFC Jember yang beralamat di Jalan Gajah Mada No.74, Jember Kidul, Kaliwates, Kabupaten Jember, Jawa Timur 68132. Penelitian ini dilakukan selama tiga bulan untuk survei dan 
pengumpulan data terkait. Diawali pada bulan Juni 2018 sampai dengan Agustus 2018.

\section{Teknik Pengumpulan Data}

Adapun teknik pengumpulan data yang digunakan oleh penulis dalam penelitian yaitu:

\section{Teknik Wawancara}

Wawancara adalah percakapan dengan maksud tertentu. Percakapan itu dilakukan oleh dua pihak, yaitu pewawancara (interviewer) yang mengajukan pertanyaan dan terwawancara (Interviewee) yang memberikan jawaban atas pertanyaan itu (Moleong, 2011:186). Dalam penelitian ini, penulis melakukan wawancara semi terstruktur dengan teknik wawancara in-depth interview, yang merupakan merupakan metode pengumpulan data yang sering digunakan dalam penelitian kualitatif. In-depth interview adalah proses memperoleh keterangan untuk tujuan penelitian dengan cara tanya jawab sambil bertatap muka antara pewawancara dengan informan atau orang yang diwawancarai, dengan atau tanpa menggunakan pedoman (guide) wawancara, pewawancara dan informan terlibat dalam kehidupan sosial yang relatif lama. (Boyce and Neale, 2006:3).

\section{Teknik Dokumentasi}

Teknik dokumentasi adalah cara pengumpulan data dengan menggunakan dokumen-dokumen yang berhubungan dengan penelitian tersebut atau mencari data mengenai hal-hal atau variabel berupa catatan, transkrip, buku, surat kabar, majalah, prasasti, legger, notulen, rapat agenda dan lain sebagainya (Suharsimi, 2002:206). Penulis menggunakan teknik dokumentasi dengan cara mengumpulkan data yang berkaitan dengan metode pelatihan dan pengembangan karyawan KFC Jember

\section{Teknik Observasi}

Teknik observasi adalah pengamatan langsung kepada obyek yang akan diteliti (Gorrys Keraf, 2001:116). Observasi adalah kemampuan seseorang untuk menggunakan pengamatannya melalui hasil kerja pancaindra mata serta dibantu 
dengan pancaindra lainnya (Bungin, 2009:118). Jenis observasi / pengamatan yang digunakan pada penelitian ini adalah berperan serta sebagai pengamat. Yang dimaksud dengan pengamatan jenis ini bahwa dalam teknik tersebut peneliti sebagai pengamat tidak sebagai pemeran serta, tetapi melakukan fungsi pengamatan. Misal peneliti berada di sudut ruangan untuk melihat dan mencatat bagaimana subjek yang diteliti menggunakan waktu kerjanya di kantor ataupun cara bekerjanya (Tohirin, 2012:62). Teknik ini penulis lakukan dengan cara meninjau langsung ke lokasi KFC Jember.

\section{Jenis Data Penelitian}

Di dalam penelitian ini peneliti menggunakan jenis data kualitatif. Data kualitatif adalah data yang bersifat tidak terstruktur, dalam arti variasi data yang diberikan oleh sumbernya beragam dengan tujuan untuk memperoleh pandangan yang mendalam dan meluas dari setiap informan penelitian (Istijanto, 2005:46). Peneliti menggunakan dua sumber data, yaitu data primer dan data sekunder. Data primer adalah data yang langsung diperoleh dari sumber data pertama di lokasi penelitian atau objek penelitian. Data primer diperoleh melalu hasil observasi atau wawancara. (Bungin, 2009:122). Data primer yang digunakan adalah hasil wawancara dengan Bapak Dodik Setiadi (nama disamarkan), selaku manajer di KFC Jember dan supervisornya serta 5 orang karyawan yang bekerja di restoran tersebut untuk mengetahui bagaimana proses pelatihan dan pengembangan pada KFC Jember. Data sekunder adalah data yang diperoleh dari hasil pengumpulan orang lain.

\section{Populasi dan Sampel Penelitian}

Theoretical sampling yang digunakan pada penelitian ini adalah purposive sampling. Purposive sampling yaitu teknik penarikan sampel dengan menentukan kelompok peserta yang menjadi informan sesuai dengan kriteria tepilih yang relevan dengan masalah penelitian (Sugiyono, 2012). Kunci dasar dari purposive sampling ini adalah penguasaan informasi dari informan dan secara logika bahwa 
tokoh-tokoh kunci di dalam proses sosial selalu langsung menguasai informasi yang terjadi di dalam proses sosial itu (Bungin, 2009:107). Peneliti menggunakan teknik tersebut karena peneliti ingin para informan yang dipilih benar-benar sesuai dan tepat dengan kebutuhan penelitian.

\section{HASIL PENELITIAN DAN PEMBAHASAN}

\section{Gambaran Umum KFC Jember}

KFC (Kentucky Fried Chicken) salah satu restoran rantai terbesar di dunia. yang berkantor pusat di Louisville, Kentucky, Amerika Serikat. Sebuah "ikon Amerika" restoran terbesar kedua setelah McDonald, dengan lebih 17.000 outlet di 105 negara dan berapa wilayah. KFC didirikan oleh Kolonel Harland Sanders, yang mulai menjual ayam goreng nya dari pinggir jalan restoran di Corbin, Kentucky. Kolonel Sanders atau Harland David Sanders Lahir: 9 September 1890 dan meninggal tanggal 16 December 1980. Lahir dan dibesarkan di Henryville, Indiana. Kolonel Sanders melewati beberapa profesi dalam hidup, dengan keberhasilan yang beragam.

Kolonel Sanders menjual ayam goreng buatannya pada tahun 1930 ditengah tengah depresi besar, disebuah pompa bensin milikinya Corbin Utara sebuah kota kecil di tepi Pegunungan Appalachian selatan timur Kentucky. Ruangan makan bernama Sanders Court \& Café, yang dibilang cukup berhasil dan dia diberi gelar kehormatan Kentucky Kolonel pada tahun 1936 oleh Gubernur Kentucky Ruby Laffoon.

Tahun berikutnya restorannya diperluas menjadi 142 kursi dan dia mulai menambahkan sebuah motel yang ia beli di seberang jalan. Ketika Sanders mempersiapkan restoran ayam aslinya di North Corbin, ia menyajikan ayam dalam wajan besi, yang memakan waktu sekitar 30 menit memasak (tapi terlalu lama untuk operasi restoran). Pada Tahun 1939, Sanders mengubah proses memasak ayam goreng nya dan menggunakan Pressure Frying. sehingga sewaktu memasak sangat berkurang dibandingkan dengan digoreng. 
KFC merupakan salah satu restoran cepat saji (fast food restaurant) milik perusahaan asing yang telah masuk ke Indonesia. PT Fastfood Indonesia Tbk. adalah pemilik tunggal waralaba KFC di Indonesia, didirikan oleh Gelael Group pada tahun 1978 sebagai pihak pertama yang memperoleh waralaba KFC untuk Indonesia dan terdaftar sebagai perusahaan publik sejak tahun 1994. Perseroan mengawali operasional restoran pada saat awal bulan Oktober 1979 di Jalan Melawai, Jakarta dan telah memperoleh sukses. Kesuksesan outlet ini kemudian diikuti dengan pembukaan outlet-outlet selanjutnya di Jakarta dan perluasan area cakupan hingga ke kota-kota besar lain di Indonesia, antara lain Bandung, Semarang, Surabaya, Medan, Makassar, dan Manado. KFC Jember beralamat di Jalan Gajah Mada No.74, Jember Kidul, Kaliwates, Kabupaten Jember, Jawa Timur 68132.

KFC Jember sendiri telah berdiri sejak tahun, 2016 dan memiliki karyawan yang berjumlah 37 orang (standart minimal Restoran KFC Indonesia) dengan 5 secsion (divisi) yang terdiri dari Divisi Cashier, Dinning, Back up, Cook dan Kitchen. Semua proses pelatihan baik karyawan baru atau pemilihan bagian dilakukan di DTO (District Training Officer) yang berpusat di Plaza Surabaya.

Tabel. 1 Data Informan

\begin{tabular}{llllll}
\hline No & Nama (Disamarkan) & P/L & Umur & Pekerjaan & \\
\hline 1 & Dodik Setiadi & L & 34 & Manajer & \\
2 & Wahyu Prasetyo & L & 28 & Supervisor & \\
3 & Rangga Praditya & L & 23 & Divisi Dinning & (Calon \\
& & & & Karyawan) & \\
4 & Ratna Endah Susanti & P & 25 & Divisi Cashier & \\
5 & Ricco Setiawan & L & 23 & Divisi Kitchen & \\
6 & Yunanto Eka Pratama & L & 26 & Divisi Back up \\
7 & Airlangga & L & 14 & Divisi Cook & \\
\hline
\end{tabular}

Sumber : Data Primer 2018

\section{Hasil Data Informan}

\section{Dodik Setiadi (Nama Disamarkan)-Manager}

Pelatihan calon karyawan di KFC Indonesia dilakukan selama 2 minggu dimana minggu pertama teori dalam kelas / Metode Lecture yaitu mengajarkan teori-teori yang diperlukan didalam kelas dan minggu kedua yaitu praktek 
langsung kelapangan / on the job training yaitu bekerja sambil berlatih, sesuai yang dikemukakan oleh Subekhi \& Jauhar (2012:87). Pengembangan karyawan dilakukan dengan merotasikan karyawan yang rajin dan berprestasi ke divisidivisi lainnya dengan tujuan untuk mempelajari hal-hal baru, hal ini sesuai dengan yang diungkapkan oleh Mangkunegara (2001:57) tentang job rotasi yaitu metode pengembangan yang melibatkan perpindahan peserta dari satu pekerjaan ke pekerjaan lainnya. Di divisi yang baru junior dibimbing oleh senior di divisi tersebut dengan menggunakan metode pelatihan Mangkunegara (2001:57) yaitu on the job training, Subekhi \& Jauhar (2012:87). Dalam untuk pengembangan manager, calon manager dipersiapkan langsung oleh manager dengan menggunakan metode understudy yaitu mempersiapkan peserta untuk melaksanakan pekerjaan atau mengisi suatu posisi jabatan tertentu. Konsep understudy merupakan suatu teknik perencanaan pegawai yang berkualifikasi untuk mengisi jabatan manajer, sesuai dengan yang dikemukakan oleh Mangkunegara (2001:57).

\section{Wahyu Prasetyo (Nama Disamarkan)-Supervisor}

Tujuan dilakukan pelatihan calon karyawan di KFC Jember adalah untuk meningkatkan skill karyawan supaya sesuai dengan standart KFC Indonesia dalam peningkatan keselamatan kerja, penghematan cost control, karena dipantau dari pusat : listrik, air, dan gas. Hal ini sesuai dengan beberapa tujuan yang dikemukakan oleh Mangkunegara (200:45) yaitu meningkatkan kualitas kerja, meningkatkan kesehatan dan keselamatan kerja, dan juga meningkatkan produktivitas kerja. Tujuan dilakukan pengembangan karyawan di KFC Jember adalah untuk meningkatkan skill / kualitas kerja karyawan, meminimalisasi kesalahan dalam bekerja, mengajak karyawan menjadi senior, meringankan tugas manager dan supervisor sesuai dengan beberapa tujuan yang dikemukakan oleh Hasibuan (2005:70) yaitu meningkatkan produktivitas kerja, efisiensi waktu, meminimalisasi kesalahan, meningkatkan moral, dan juga untuk jenjang karir. 


\section{Rangga Praditya (Nama Disamarkan) -Divisi Dinning (calon karyawan)}

Proses pelatihan baik karyawan baru atau pemilihan bagian dilakukan di DTO (District Training Officer) yang berpusat di Plaza Surabaya. Pelatihan calon karyawan dilakukan dalam 2 minggu, minggu pertama teori dalam kelas / metode Lecture yaitu mengajarkan teori-teori yang diperlukan didalam kelas. Dinning bertanggung jawab pada kebersihan area depan, tugasnya meng clear up pringpiring dan meja. Pelatihan yang diberikan adalah Modul CSTM (Customer Service Team Leader). Minggu kedua yaitu praktek langsung kelapangan / on the job training yaitu bekerja sambil berlatih, sesuai yang dikemukakan oleh Subekhi \& Jauhar (2012:87). Informan berharap agar dapat mengikuti prosedur yang telah ditentukan oleh restoran.

\section{Indah Susanti (Nama Disamarkan)-Divisi Cashier}

Proses pelatihan baik karyawan baru atau pemilihan bagian dilakukan di DTO (District Training Officer) yang berpusat di Plaza Surabaya. Pelatihan dilakukan 14 hari sebelum bekerja, saat pelatihan di ajarkan teori terlebih dahulu didalam kelas selama 1 minggu, setelah itu baru praktek selama 1 minggu dengan didampingi tim training. (Subekhi \& Jauhar, 2012: 87). Cashier atau disebut juga sebagai ujung tombak karena di situlah awal mula tentang penilaian kepuasan pelanggan, dengan tugas menerima pesanan dan penyampaian produk-produk yang dijual. Pelatihan untuk Cashier adalah Modul Customer Service, dengan mempelajari body language dan eye concact kepada pelanggan. Pengembangan karyawan dilakukan dengan merotasikan karyawan yang rajin dan berprestasi ke divisi-divisi lainnya dengan tujuan untuk mempelajari hal-hal baru, hal ini sesuai dengan yang diungkapkan oleh Mangkunegara (2001:57) tentang job rotasi yaitu metode pengembangan yang melibatkan perpindahan peserta dari satu pekerjaan ke pekerjaan lainnya. Di divisi yang baru junior dibimbing oleh senior di divisi tersebut dengan menggunakan metode pelatihan Mangkunegara (2001:57) yaitu on the job training, Subekhi \& Jauhar (2012:87). Informan berharap agar bisa lebih prosedur lagi dalam bekerja. 


\section{Ricco Setiawan (Nama Disamarkan) - Divisi Kitchen}

Proses pelatihan baik karyawan baru atau pemilihan bagian dilakukan di DTO (District Training Officer) yang berpusat di Plaza Surabaya. Pelatihan dilakukan selama14 hari dimana hari 1-7 didalam kelas diajarkan tentang teori lalu diberi test, hari ke 8-14 praktek langsung kelapangan didampingi tim training (Subekhi \& Jauhar, 2012:87). Divisi Kitchen yang mempunyai bagian memasak nasi, sup, perkedel dan mencuci piring-piring kotor. Pelatihan adalah Modul Food Safety Team Member. Pengembangan karyawan dilakukan dengan job rotasi ke setiap divisi yang baru, nantinya di divisi yang baru akan dibimbing oleh senior di divisi itu dan juga oleh tim training yang datang berkunjung (Mangkunegara, 2001:57). Informan berharap agar program pelatihan dan pengembangan ini bisa meningkatkan kualitas KFC Jember menjadi yang terbaik, dan juga memberikan kepuasan terhadap customer dengan produk-produk yang berkualitas.

\section{Yunanto Eka Pratama (Nama Disamarkan)-Divisi Back Up}

Proses pelatihan baik karyawan baru atau pemilihan bagian dilakukan di DTO (District Training Officer) yang berpusat di Plaza Surabaya. Pelatihan dilakukan selama kurang lebih 2 minggu, minggu pertama belajar teori-teori dasar didalam kelas. (Subekhi \& Jauhar, 2012:87). Back Up bertanggung jawab menyiapkan produk - produk yang sudah matang, yakni memiliki peran membantu tugas Cashier. Pelatihan yang diberikan adalah Modul Supply Base. Minggu kedua praktek langsung membantu senior tetapi dengan pendampingan tim training (Subekhi \& Jauhar, 2012: 87). Informan berharap agar program pelatihan ini bisa membuatnya menjadi orang yang berguna, baik untuk keluarga maupun perusahaan.

\section{Airlangga (Nama Disamarkan)-Divisi Cook}

Proses pelatihan baik karyawan baru atau pemilihan bagian dilakukan di DTO (District Training Officer) yang berpusat di Plaza Surabaya. Pelatihan dilakukan selama kurang lebih 2 minggu, minggu pertama belajar teori-teori dasar didalam kelas. (Subekhi \& Jauhar, 2012:87). Cook yakni bertugas hanya menggoreng ayam. Pelatihan yang diberikan adalah Modul Food Safety Team Member. 
Minggu kedua praktek langsung membantu senior tetapi dengan pendampingan tim training (Subekhi \& Jauhar, 2012: 87). Informan berharap agar program pelatihan ini bisa membuatnya menjadi orang yang berguna, baik untuk keluarga maupun perusahaan.

\section{Analisis Pelatihan Calon Karyawan}

Proses pelatihan baik karyawan baru atau pemilihan bagian dilakukan di DTO (District Training Officer) yang berpusat di Plaza Surabaya. Disana proses pelatihan berlangsung selama 2 minggu dan dengan menggunakan 2 metode pelatihan seperti yang dikemukakan oleh Subekhi \& Jauhar (2012:87). Metode yang pertama adalah Lecture (ceramah atau kuliah) yaitu mempelajari teori didalam kelas selama 1 mingu, dimana pelatih mengajarkan teori-teori yang diperlukan, sedangkan yang dilatih mencatat serta mempresentasikan. Di dalam kelas hari pertama sampai ke 4, calon karyawan diajarkan berbagai macam teori seperti sejarah berdirinya KFC Indonesia, prosedur-prosedur dasar, bagaimana memberikan good quality service kepada customer dari datang sampai meninggalkan restoran dan disana juga dijelaskan semua job description yang ada di Restoran KFC Indonesia, sedangkan di hari ke 5 dan 6 lebih di fokuskan ke job description yang lebih spesifik, yaitu job description dari divisi calon karyawan tersebut. Lalu pada hari yang ke 7 dilakukan test untuk menguji sejauh mana pemahaman dan penguasaan materi yang di ajarkan oleh tim training.

Metode yang kedua adalah $O n$ the job training yaitu melatih seseorang untuk mempelajari sebuah pekerjaan sekaligus dengan mempraktekkannya. Pada metode ini sumber daya manusia yang baru akan dilatih sekaligus bekerja dibawah pengawasan tim training, sehingga bila terjadi sesuatu hal yang tidak dimengerti, bisa bertanya kepada tim training tersebut, dalam hal ini tim training akan mendampingi para calon karyawan selama seminggu yaitu pada hari ke 8 sampai hari ke 14.

Kedua metode di atas sangat efektif digunakan dalam melatih calon karyawan di KFC Indonesia, dengan dibekali teori terlebih dahulu calon karyawan jadi 
mempunyai gambaran tentang pekerjaan yang akan dilakukannya nanti, dan baru setelah itu dilatih dengan pelatihan sambil bekerja, calon karyawan yang masih belum mengerti bisa diarahkan dan dibimbing sampai calon karyawan tersebut mengerti dengan prosedur kerjanya. Tujuan dilakukan pelatihan calon karyawan di KFC Jember adalah untuk meningkatkan skill karyawan supaya sesuai dengan standart KFC Indonesia, meningkatkan keselamatan kerja, menghemat cost control, karena dipantau dari pusat : listrik, air, dan gas. Hal ini sesuai dengan beberapa tujuan yang dikemukakan oleh Mangkunegara (2001:45) yaitu meningkatkan kualitas kerja, meningkatkan kesehatan dan keselamatan kerja, dan juga meningkatkan produktivitas kerja.

Kelebihan metode pelatihan on the job training yang digunakan oleh KFC Indonesia adalah : (1) Pekerjaan yang dilakukan adalah pekerjaan sesungguhnya, sehingga calon karyawan bisa lebih cepat mengenal situasi kerjanya (orientasi pekerjaan). (2) Calon karyawan mendapatkan pelatihan khusus dibidang pekerjaannya. (3) Pelatihan dibimbing langsung oleh karyawan yang lebih senior dan lebih berpengalaman dan tentunya juga didampingi oleh tim training. (4) Tidak perlu fasilitas khusus karena pelatihanya ditempat kerja sesungguhnya. (5) Karyawan bisa bekerja sambil mendapatkan pelatihan. (6) Tidak menyita waktu yang banyak dan biaya relatif rendah.

Kekurangan metode pelatihan on the job training yang digunakan oleh KFC Indonesia adalah : (1) Karyawan senior mungkin tidak dapat sepenuhnya dalam membimbing, karena terbentur pada pekerjaannya, seperti customer yang menuntut segala sesuatunya serba cepat, sehingga memakan waktu apabila harus mengajarkan step by step dan apabila karyawan senior tidak mempunyai motivasi yang tinggi, maka dalam pembimbingan kurang dapat maksimal. (2) Meskipun dibimbing oleh senior dan didampingi oleh tim training yang profesional, resiko kesalahan dalam praktek masih bisa terjadi, seperti gosong dalam menggoreng ayam / kentang, jumlah takaran yang tidak pas, dll. Tentu saja hal ini akan menghambat proses pekerjaan. 


\section{Analisis Pengembangan Karyawan}

Tujuan dilakukan pengembangan di KFC Jember adalah untuk meningkatkan skill / kualitas kerja karyawan, meminimalisasi kesalahan dalam bekerja, mengajak karyawan menjadi senior, meringankan tugas manager dan supervisor sesuai dengan beberapa tujuan yang dikemukakan oleh Hasibuan (2005:70) yaitu meningkatkan produktivitas kerja, efisiensi waktu, meminimalisasi kesalahan, meningkatkan moral, dan juga untuk jenjang karir.

Dalam metode pengembangan karyawan, karyawan yang dipilih untuk dikembangkan adalah karyawan yang berpotensi dan rajin. Manager dan supervisor sendiri yang akan memantau kinerja tiap karyawan dan memberikan penilaian. Setelah beberapa bulan bekerja di divisi, karyawan yang dianggap berpotensi dan telah menguasai / mahir dalam pekerjaannya akan diangkat sebagai senior di divisi tersebut atau bisa juga dipindahkan / dirotasikan ke divisi lain untuk mempelajari hal-hal yang baru, hal ini sesuai dengan yang diungkapkan oleh Mangkunegara (2001:57) tentang job rotasi yaitu metode pengembangan yang melibatkan perpindahan peserta dari satu pekerjaan ke pekerjaan lainnya.

Menurut Mangkunegara (2001:57) metode pelatihan juga sering digunakan dalam pengajaran pengembangan. Dalam hal ini karena di KFC Jember ada 4 divisi : cashier, waitress, kitchen, dan preparation, maka biasanya karyawan yg rajin dan berpotensi untuk dikembangkan akan dirotasikan kesetiap divisi tersebut, setiap dipindahkan ke divisi yang baru, karyawan tersebut akan dibimbing oleh senior di divisi tersebut yaitu dengan menggunakan metode pelatihan on the job training, Subekhi \& Jauhar (2012:87)

Karyawan yang sudah pernah mencoba semua divisi tersebut dan dianggap berpotensi akan di promosikan oleh manager sebagai calon supervisor, karena setiap 2 tahun sekali dari pusat meminta daftar nama karyawan berpotensi untuk dipromosikan sebagai calon supervisor, untuk di tempatkan kecabang-cabang lain yang membutuhkan.

Pengembangan manager, biasanya calon manager ditunjuk langsung oleh pusat dan pusat menyuruh manager untuk mempersiapkan orang tersebut untuk 
menduduki posisi manager, yang dipersiapkan biasa supervisor yang telah lama bekerja dan berprestasi dan dianggap cukup pantas untuk dipromosikan. Metode yang digunakan adalah sesuai dengan yang dikemukakan oleh Mangkunegara (2001:57) dengan understudy yaitu mempersiapkan peserta untuk melaksanakan pekerjaan atau mengisi suatu posisi jabatan tertentu. Konsep understudy merupakan suatu teknik perencanaan pegawai yang berkualifikasi untuk mengisi jabatan manajer. Teknik pengembangan understudy serupa dengan metode on the job, belajar dengan berbuat yang ditekankan melalui kebiasaan yaitu dengan bertugas membantu tugas-tugas manager sehingga dengan demikian supervisor (calon manager) sudah mempunyai gambaran dan bisa memahami tentang tugastugas dan tanggung jawab apa saja yang dimiliki saat nanti menjabat sebagai seorang manager.

\section{Analisis Pelatihan dan Pengembangan}

Pelatihan dan pengembangan yang dilakukan KFC Jember telah memenuhi unsur-unsur pelatihan dan pengembangan seperti, (1) tujuan dan sasaran pelatihan dan pengembangan sudah jelas seperti yang telah dibahas sebelumnya, (2) lalu KFC Jember memiliki tim training yang profesional dari pusat, (3) materi pelatihan dan pengembangan telah sesuai dengan tujuan yang hendak dicapai yaitu meminimalkan cost control agar perusahaan profit, (4) para calon karyawan dan karyawan dapat mengikuti program pelatihan dan pengembangan sesuai dengan prosedur, (5) calon karyawan di tes psikologi terlebih dahulu sebelum mengikuti pelatihan, sedangkan karyawan yang akan mengikuti pengembangan dipantau langsung kinerjanya oleh manager dan supervisor dan diberi penilaian apakah karyawan ini termasuk rajin untuk bisa mengikuti metode pengembangan yang ada. Hal ini sesuai dengan yang dikemukakan oleh Mangkunegara (2001:44), tentang beberapa unsur-unsur pelatihan dan pengembangan yang dilakukan kepada sumber daya manusia yaitu : (1) Tujuan dan sasaran pelatihan serta pengembangan harus jelas dan dapat diukur, hal ini perlu agar sumber daya manusia tahu kompetensi apa yang harus dicapai setelah mengikuti pelatihan yang 
dilakukan oleh organisasi. (2) Para pelatih harus memiliki kualifikasi yang memadai, hal ini perlu agar sumber daya manusia bisa memahami materi latihan. (3) Materi latihan dan pengembangan harus disesuaikan dengan tujuan yang hendak dicapai, sehingga pelatihan dilakukan atas tujuan dan dasar yang kuat, tidak asal-asalan melakukan pelatihan. (4) Metode pelatihan dan pengembangan harus sesuai dengan tingkat kemampuan sumber daya manusia, sehingga sumber daya manusia tersebut bisa menyerap materi yang diberikan oleh pelatih. (5) Peserta pelatihan dan pengembangan harus memenuhi persyaratan yang ditentukan.

Pelatihan dan pengembangan yang dilakukan di KFC Jember belum terlalu memenuhi faktor-faktor dalam pelatihan dan pengembangan, seperti didalam penempatan divisi untuk calon karyawan, karyawan tidak dapat memilih divisi yang diinginkan, tetapi langsung ditentukan oleh pusat, hal ini tentu saja belum memperhatikan faktor perbedaan individu setiap SDM seperti kemampuan yang berbeda, kepandaian dan juga motivasi yang berbeda. Tetapi ada sebagian juga faktor yang telah diperhatikan KFC Jember seperti dalam pelatihan calon karyawan, sebelum mengikuti program tersebut diadakan tes psikologi untuk menyeleksi calon karyawan yang mempunyai kemampuan dan motivasi, sehingga hanya yang memenuhi kualifikasi yang bisa mengikuti pelatihan.

\section{KESIMPULAN DAN SARAN}

\section{Kesimpulan}

Berdasarkan analisis dan pembahasan pada Bab 4 maka kesimpulan dalam penelitian ini adalah metode pelatihan calon karyawan yang digunakan KFC Jember adalah Lecture yaitu mempelajari teori didalam kelas selama 1 minggu dan on the job training yaitu praktek bekerja sambil berlatih selama 1 minggu juga. Metode pengembangan karyawan yang digunakan KFC Jember adalah job rotasi yaitu dengan memindah-mindahkan karyawan ke divisi yang berbeda-beda, lalu dengan memakai kembali metode pelatihan (on the job training) dan 
understudy. Pelatihan calon karyawan dan pengembangan karyawan yang dilakukan telah sesuai dengan prosedur yang telah ditetapkan oleh perusahaan.

\section{Saran}

Saran yang diberikan dalam penelitian ini, yang pertama, pelatihan calon karyawan dan pengembangan karyawan yang telah ditetapkan haruslah terus dijalankan sesuai dengan prosedur yang ada dan prosedurnya harus dilaksanakan secara jelas dan berkelanjutan guna meningkatkan kompetensi dan komitmen karyawan untuk menjadi karyawan yang berkualitas dan kompeten. Yang kedua di dalam mengembangkan karyawan, jangan hanya memilih karyawan yang berpotensi dan rajin saja, tetapi karyawan yang malas juga harus didorong atau bahkan diwajibkan untuk mengikuti program pengembangan setiap beberapa bulan, sehingga setiap karyawan merasa di support oleh perusahaan, sehingga mereka merasa terpacu untuk tidak bermalas-malasan, dan berlomba-lomba untuk dipromosikan dan juga progam pengembangan bisa membuat pikiran mereka bisa lebih terbuka dalam bekerja.

Ketiga hasil evaluasi program pengembangan karyawan harus disampaikan secara transparan kepada karyawan yang mengikuti program pengembangan, agar karyawan yang kurang berkompetensi dapat diwajibkan untuk mengikuti program pengembangan kembali dengan metode pelatihan. Adanya program pelatihan calon karyawan dan pengembangan karyawan diharapkan pihak perusahaan dapat melaksanakan pelatihan calon karyawan dan pengembangan karyawan dengan penuh tanggung jawab sesuai dengan peraturan yang ada dan begitu pula dengan karyawan diharapkan mengikuti peraturan tersebut. Hal ini bertujuan untuk memudahkan perusahaan mencapai tujuannya dan meningkatkan kualitas kerja sumber daya manusia didalam perusahaan. 


\section{DAFTAR PUSTAKA}

Arikunto S. 2002. Prosedur Penelitian Suatu Pembahasan. Jakarta: Bhineka Cipta.

Ardana et al, 2012, Manajemen Sumber Daya Manusia, Jakarta : Cetakan Pertama, Graha Ilmu.

As'ad, M, 1991, Seri Ilmu Sumber Daya Manusia : Psikologi Industri, Edisi IV, Yogyakarta : Liberty

Bungin, B. (2009). Penelitian kualitatif. Jakarta: Prenada Media Group.

Burtonshaw \& Gun. 2011. Alat dan Teknik Analisis Manajemen. PT.Indeks Jakarta

Dharma. 2011. Manajemen Kinerja. Yogyakarta : Pustaka Pelajar

Dessler, G. 2011. Human Resource Management. McGraw-Hill. Series In Management. New York.

Findarti. 2016. Pengaruh Pengembangan Sumber Daya Manusia Terhadap Kinerja Pegawai Pada Kantor Badan Kepegawaian Daerah Provinsi Kalimantan Timur. eJournal Ilmu Administrasi Bisnis, 2016, 4 (4): 937-946 ISSN 2355-5408, ejournal.adbisnis.fisip-unmul.ac.id

Garavan. et al. 2001. "Akumulasi Human Capital: Peran Pengembangan Sumber Daya Manusia"e. Journal of European Pelatihan Industri, 25 (2/3/4), 48-68.

George et al, 2002, Organizational Behavior, Third Edition, Pearson Education, Inc, Upper Saddle River, New Jersey.

Gibson et al, 1992, Organisasi : Perilaku, Struktur dan Proses, Jilid I, Edisi V alih Bahasa : Djarkasin, Jakarta, Erlangga.

Gomes, F.C. (1995). Manajemen Sumber Daya Manusia edisi 2. Yogyakarta: Andi Offset.

Handoko, T. H. (2001). Manajemen Personalia dan Sumber Daya Manusia. BPFE, Yogjakarta.

Hasibuan, 1997, Organisasi dan Motivasi, Dasar Peningkatan Produktifitas, Cetakan Pertama, Jakarta : Bumi Aksara.

--------, 2000, Manajemen Sumber Daya Manusia, Jakarta : Bumi Aksara.

-------, 2011, Manajemen Dasar, Pengertian, dan Masalah, Cetakan ke 9, Jakarta: Bumi Aksara.

Koestartini, 1997, Manajemen Personalia, Jakarta : Ghalia Indonesia. 
Komaruddin. 1992. Manajemen Pengawasan Kualitas Terpadu suatu Pengantar. Jakarta: Rajawali Press.

Kuncoro, M, (2003), Metode Riset untuk Bisnis dan Ekonomi, Penerbit Erlangga, Jakarta.

Kusriyanto. 1993. Meningkatkan Produktivitas Karyawan. Jakarta. PT. Pustaka Binaman Pressindo.

Mangkunegara, A.P. (2011). Evaluasi Kinerja Sumber Daya Manusia. Bandung: Refika Aditama.

(2001) Manajemen Sumber Daya Manusia Perusahaan. Bandung: Remaja Rosdakarya.

Mathis, RL \& Jackson. (2001). Manajemen Sumber Daya Manusia, jilid 1 (Alih Bahasa Jimmy Sadeli dan Bayu Prawira). Jakarta: Penerbit Salemba

Moleong, L. J. ( 2011 ). Metode penelitian kualitatif ( edisi revisi). Bandung: PT. Remaja Rosdakarya.

Mondy \& Noe,1995, Human Resource Management, Massahusetts, Allyn \& Bacon

Nitisemito. (1996), Manajemen Personalia (Manajemen Sumber Daya Manusia), Edisi Revisi, Cetakan Kedelapan, Ghalia Indonesia, Jakarta.

Rivai dan Ella. 2011. Manajemen Sumber Daya Manusia Untuk Perusahaan, cetakan keempat, Jakarta: Rajagrafindo Persada

Sanusi. A.2011. Metodologi Penelitian Bisnis. Salemba Empat. Jakarta. Indonesia

Sarwono, 1993, Sumberdaya Manusia kunci Sukses Organisasi, Jakarta ,Lembaga Manajemen Universitas Indonesia.

Schuller dan Jackson. 1988. "Customerizing the Human Resources Department". Personnel. June: 36-44.

Sedamaryanti, 2007, Manajemen Sumbet Daya Manusia ( Reformasi Birokrasi dan Manajemen Karyawan Sipil ), Bandung : Penerbit PT Refika Aditama.

Sekaran. 2011. Research Methods for Business: A Skill-Building Approach. Forth Edition. Salemba Empat; Jakarta.

Simamora. (2006). Manajemen Sumber Daya Manusia, edisi 3. Yogyakarta: Bagian Penerbitan Sekolah Tinggi Ilmu Ekonomi YKPN.

Steele-Johnson et al (2000), Goal Orientation and Task Demand Effects on Motivation, Affect and Performance, Journal of Applied Psychology, Vol. 85, 724-738. 


\section{Volume 3 , Nomor 2,}

Sugiyono. (2012). Metode Penelitian Kuantitatif, Kualitatif dan R\&D. Bandung: Alfabeta.

Suhartini, H., (1992), Pengaruh Metode Pengelolaan Diri Sendiri Terhadap Prestasi Kerja Praktek Harian, Jurnal Psikologi, No. 1., 25-30.

Syarif. 1991. Produktivitas. Jakarta: Depdikbud.

Saydam. (2000). Manajemen Sumber Daya Manusia (Human Resource Management): Suatu Pendekatan Mikro (Dalam Tanya Jawab). Cetakan Kedua. Jakarta: Penerbit Djambatan.

Tohirin. (2012). Metode penelitian kualitatif. Jakarta: PT RajaGrafindo Persada.

Tilon. DA. 2013. Pelatihan Dan Pengembangan Sumber Daya Manusia Pada Restoran A\&W Di City Of Tomorrow Surabaya. Jurnal AGORA Vol 1 No.3.

Umar, H, (2005). Evaluasi kinerja, Jakarta : Gramedia Pustaka Utama.

Woekirno. 1979. Faktor-Faktor Produktivitas Karyawan. Jakarta: Gramedia.

https://id.wikipedia.org/wiki/KFC diakses pada tgl. 28/05/2018

http://tesyazulvaaprilia.blogspot.com/2014/11/profilsejarah-dan-modal-awal-kfc.html diakses pada tgl. 28/05/2018 